\title{
Patella aplasia/hypoplasia
}

INSERM

\section{Source}

INSERM. (1999). Orphanet: an online rare disease and orphan drug data base. Patella aplasia/hypoplasia. ORPHA:86789

Isolated patella aplasia-hypoplasia is an extremely rare genetic condition characterized by congenital absence or marked reduction of the patellar bone described in only a few families to date. 